\title{
Tourism Zoning of Area for Sustainable Development of the Example of Khabarovsky Krai
}

\author{
Zoya G. Mirzekhanova \\ Irina D. Debelaia \\ Institute for Aquatic and Ecological Problems of Far Eastern Branch Russian \\ Academy of Sciences, Pacific National University, Russian Federation \\ Email:lorp@ivep.as.khb.ru
}

\section{Doi:10.5901/mjss.2015.v6n3s5p283}

\begin{abstract}
Khabarovsky Krai has been presented as a sample model of the area to be zoned for sustainable development. It is an area with high natural tourism capacity but poorly developed as far as tourism is concerned. The analysis of zoning criteria has been made. The Khabarovsky krai map of tourism zoning makes it possible to evaluate the prospective tourism activities identifies in the regions, provinces and districts with the account of tourist resources and the relevant infrastructure. The resulting materials were used in the development of the regional target program "Development of internal and external tourism in the Khabarovsk Krai (2013-2020)".
\end{abstract}

Keywords: sustainable development, tourism resources, maps of tourism zoning, tourist area, tourist province, tourist districts

\section{Introduction}

Tourism is the priority direction of sustainable development of Russia. Regions of the Far East are determined by intensive development of tourist services. The resource potential of the Khabarovsky Krai as a tourist attraction area is not only significant and diverse but also perspective for development as it has unique cultural and natural heritage specific to the Russian Far East. Diverse touristic resources need systematizing and certain regularizing. There are several techniques that allow systematizing tourist attractions by certain properties and concrete logical description according to the tasks set. Resource zoning using the cartography method is one of the most useful procedures for systematization of tourist attractions and areas to increase the development of domestic tourism. Actual task is definition of 'growth points' - perspective territories where creation of a quality tourist product is possible.

Resource zoning using the cartography method is one of the most useful procedures for systematization of tourist attractions and areas to increase the development of domestic tourism. That is why mapping support, namely the compilation of the map 'Khabarovsky Krai Tourism Zoning', may serve as an effective tool for regional sustainable development. Thus, the purpose of the research is Khabarovsk Krai tourism zoning for sustainable development and recommendations about optimization of functioning of main types for tourism.

\section{Tourism Zoning: A Literature Review}

Zoning is a scientific methodical technique that uses imaginary division of a certain territory into parts based on concrete features, specified criteria and understanding that if the selected criteria undergo alterations, the zoning pattern would be inevitably changed (Isachenko, 2004).

Modern concepts of territory zoning allow implicating different criteria that may produce a multitude of overlapping zoning systems (climatic, landscape, etc.). That is why a universal zoning map is hardly possible. Thus, a tourism zoning set may include such components as location of most attractable tourist resources within natural taxonomic entities, functionality of tourist resource use, tourist resource accessibility, tourist infrastructure development level, etc. Although any of the mentioned criteria may be selected for zoning, still regional natural and historical development specifics of the region will inevitably manifest themselves in the character and development tendencies of both natural ecosystems and social and historical systems. These natural and socio-cultural objects mostly attract a newcomer and as such are the prerequisites for developing regional tourist potential. 
Recreation zoning (tourism zoning being a part of recreation zoning) is an industry zoning, which describes territory specifics from the point of view of industry actual development and its future perspectives in a particular region. Neither uniformed methods of recreation zoning nor theoretical and practical guidelines have been developed so far. Some attempts have been made in the USSR.

Up to now, there are no uniform methods of recreational zoning and its theoretical and practical guidelines are not sufficiently developed. There are some examples of recreational zoning undertaken in the USSR based on recreation object density. Zoning of Georgia (Kobakhidze, 1978), Azerbaidzhan (Kotlyarov, 1978), Kaliningrad oblast (Dragiliva \& Korneevets 2004; Kropinova \& Mitrofanova 2010) was based on recreation and health facility share in regional economy and population employment in recreation services.

Present studies view recreational zoning as an industry economic and geographic zoning being a part of general zoning of economy, where regional specialization is described as engagement of the majority of regional population in recreational and tourist business and related service industries. Such views cannot be applied to tourist zoning of those Russian Federation regions, which are characterized with weak territory development and absence of permanent population and, thus absence of transport and hospitality infrastructure. Examples of recreation zoning based on natural prerequisites are well-known and are briefly described in literary sources. Recreation zoning by natural criteria was based on physical geographical zoning of the territory.

\section{Research Methodology}

Tourism zoning - is the scientific universal methodical reception connected with division of the territory by certain signs. Result of tourism zoning is the map on which taxonomical objects are displayed. There are specifics of tourism zoning. Procedure of carrying out tourism zoning as a private type of recreational zoning, it is based on the analysis of territorial specifics of the region and features of its social and economic development. Natural and welfare tourist objects make prerequisites for formation of a qualitative regional tourist product.

General geographical principles of tourism zoning: 1) objectivity - regional formation signs that reflected definite characteristics; 2) complexity of an assessment - allowed to consider a variety of tourism types; 3) hierarchy allowed to distinguish taxonomical units for territories of Khabarovsk territory, which have an accurate interconnection and submission; 4) constructability determined the clearness of the tasks set at tourist zoning.

Choice of operational unit territory partitioning: 1) tourism zoning within borders of administrative division; 2) tourism zoning within borders of natural territorial complexes.

The image of the region is gradually assigned to Khabarovsk Krai with development of the natural focused tourism. The basis of allocation of territorial units and their taxonomical submission within Khabarovsk territory - is the use of the compilation and a combination of the tourist resources, which predetermines possible development of these or those types of tourism within large natural complexes.

\section{Findings and Discussion}

Natural environment specifics of Khabarovsky Krai, relatively high natural resource conservation level owing to weak territory development, together with insufficient development of hospitality infrastructure and industrialization in general compared to the historically established centers of tourism in the European part of Russia make nature tourism the primary focus of tourism development. That is why this territory zoning should obviously reflect territory differentiation based on promising types of tourism to be developed utilizing natural tourist resource potential.

The result of zoning is a map that reflects different taxonomic objects selected according to the chosen criteria, hierarchy of regional priorities and tasks.

First attempts of tourism zoning of the Khabarovsky Krai territory were made at the Laboratory of Regional LandUse Optimization of the Institute of Water and Ecology Problems, Far Eastern Branch, Russian Academy of Sciences. The results also included recommendations on optimal functioning of major types of tourism activities and a complex thematic map (Figures $1-3$ ).

Maps of tourism zoning of the territory are maps of new content. Besides materials, traditional for tourist maps, these maps include extensive information on the specifics of tourist potential of the territory. They allow comparing taxonomic units of the same hierarchic rank by their content-richness and by their perspectives for tourist sector growth. Such maps not only predetermine the necessity for selecting territory units of different taxonomic level, but also provide their complex description and attract attention to areas and objects, most perspective for regional recreation industry development. Compared to other tourist maps tourism-zoning maps provide simultaneous information on several aspects: 
inventory, evaluation and recommendation.

By the accuracy of reflected information, these maps take the intermediate position between fundamental thematic maps for long and multiple use and operational maps that need constant correction and information updating. From the scientific and methodical point of view the following aspects are most important: cartographic model validity, suitability of its basic and applied potential for solving tasks of conceptual provisions and management of the tourism sector with due consideration of territory sustainable development. Such model may provide grounds for creating a rather unified system of tourist resource mapping that allows revealing interrelations between different objects and representing an adequate picture of the reality and a visual spatial image of depicted phenomena.

Compilation of tourism zoning maps of Far Eastern regions nowadays seems to be a difficult task as these regions are weakly developed and their tourist potential is studied insufficiently. Besides, methodological and methodical guidelines for such type of mapping works are still imperfect. That is why the experience of compilation of the complex thematic map 'Khabarovsky Krai Tourism Zoning' is of practical and scientific importance.

Sources of information used to create such a map included the following: cartographical, statistical, literary, sociological, documentary, field observations and expert reviews. All the obtained data were analyzed, selected, processes, and then converted into the cartographical form of legend signs. The initial cartographical information had been checked as relevant to geographical coordinates before the exact objects and phenomena were mapped.

The research tasks determined the scientific concept of the complex thematic map 'Khabarovsky Krai Tourism Zoning' (scale 1:2,000,000). As these tasks were to optimize the functioning of major tourism activities the main criterion for zoning was the localization of tourist resources, which determined the types of major tourism activities, resource actual availability and their potentially effective use within large natural complexes. Specifics of the formation and transformation of natural systems and tourism resources within such systems were also considered.

The geographical basis of the map 'Khabarovsky Krai Tourism Zoning' provides map control of all thematic layers and tourist resources, and thus allows automated processing of created data bases and compiling electronic maps. The main elements of the geographical basis, standard enough for 1:2,000,000 scale maps, are as follows: boundaries of political and administration divisions of different ranks, relief, hydrological, settlements, roads and road constructions. Following the selected concept and mapping tasks the set of reflected parameters and characteristics was created and the legend to describe them with relevant signs and text was composed. The thematic content of the map is revealed thought a complex legend that consists of two interrelated sub-sections: I - 'Tourist Zoning' and II - 'Tourist Resources' (Figures 2 and 3 ).

I. Tourist zoning. Development of tourist activities needs a systematic approach to the spatial analysis of any territory to fulfill the tasks of validation, prognosis and management of recreational resource use. That is why we shall make a more detailed description of the specifics of information mapping. This is the first sub-section of the map legend, which reflects the logical basis and the hierarchy of the phenomena to be mapped.

One of the aspects, most important from the methodical point of view in this sub-section, is the selection of the operational unit of territory division or, in other words, the object of zoning. As the «image-sight» of nature tourism dominates in Khabarovsky Krai, the selected operational unit has evident natural boundaries and the cartographic model visually reflects territory differentiation by development opportunities of various types of tourism, which use the tourist potential of natural resources. Objects of tourism zoning are individual territory-united entities, shown on the map with a single contour. In the legend, they are presented in the matrix form. 


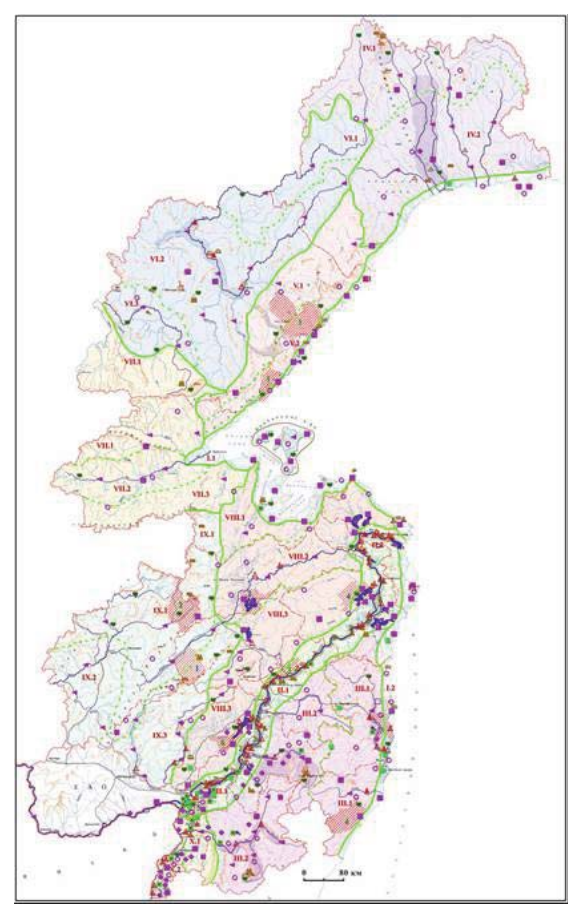

Figure 1. Khabarovsky Krai Tourism Zonin

\begin{tabular}{|c|c|c|c|}
\hline \multicolumn{4}{|c|}{$\begin{array}{c}\text { TOERIST ZONING } \\
\text { (with numbers marked on the map) }\end{array}$} \\
\hline Area & Province & District & Tourist district \\
\hline 1. Primorskaya & \begin{tabular}{|l|} 
1. Okhotomorskaya \\
2. Tatarskaya
\end{tabular} & $\begin{array}{l}\text { Ayansky } \\
\text { Shantarsky } \\
\text { Ust-Tumninsky }\end{array}$ & $\begin{array}{l}\mathrm{A}, \mathrm{Ec} \\
\mathrm{Ec} \\
\mathrm{Ec}, \mathrm{G}\end{array}$ \\
\hline 11. Priamurskaya & \begin{tabular}{|l|} 
1. Sredne-Amurnkaya \\
2Nifhne-Amunskaya
\end{tabular} & $\begin{array}{l}\text { Amur-cruises } \\
\text { Anninsky }\end{array}$ & $\begin{array}{l}\text { A, B, D, F, G } \\
\text { C }\end{array}$ \\
\hline \multirow{2}{*}{$\begin{array}{l}\text { III. Sikhote. } \\
\text { Alinskaya }\end{array}$} & 1. Vostochno- & Tumninsky & C, Ee, Ee, G \\
\hline & \begin{tabular}{|c|}
2. Zapastho- \\
Sikhote-Alinskaya \\
\end{tabular} & $\begin{array}{l}\text { Anyuisky } \\
\text { Khonsky }\end{array}$ & $\begin{array}{l}\text { Ec, Ec, D, F, G } \\
\text { Ea, Ec, Ee, F, G }\end{array}$ \\
\hline $\begin{array}{l}\text { IV. Severo- } \\
\text { Okhotskaya }\end{array}$ & 1. Suntar- Khayatinksaya & Suntanky & Ea, Ec \\
\hline v. Drugdrurskaya & $\begin{array}{l}\text { 1. Drhugdturkayay } \\
\text { 2. Pribrechnaya }\end{array}$ & Batomgsky & Ea, Ec, Ec, F \\
\hline $\begin{array}{l}\text { V1. Yudomo- } \\
\text { Maiskaya }\end{array}$ & $\begin{array}{l}\text { 1. Yudomskaya } \\
\text { 2. Maiskaya } \\
\text { 3. Uchurskaya }\end{array}$ & Nelkansky & $E c, E d, E c, F$ \\
\hline $\begin{array}{l}\text { VIL. Tokkinsko- } \\
\text { Selemdzhinskaya }\end{array}$ & $\begin{array}{l}\text { 1. Tokinsko- } \\
\text { Maiskaya } \\
\text { 2. Udkeya } \\
\text { 3. Selemdthinskaya }\end{array}$ & Geransky & Ea, Ec \\
\hline VIII. Amgunskaya & 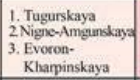 & Myaochansky & $\mathrm{Ea}, \mathrm{Eb}, \mathrm{Ec}$ \\
\hline $\begin{array}{l}\text { IX. Bureinsko- } \\
\text { Badzhalskaya }\end{array}$ & $\begin{array}{l}\text { 1. Burcinskaya } \\
\text { 2. Urgalskaya } \\
\text { 3. Badthalskaya }\end{array}$ & Uminsky & $\mathrm{Ec}, \mathrm{Ee}, \mathrm{G}$ \\
\hline $\mathrm{X}$. Ussuriiskaya & \begin{tabular}{l|} 
1. Nithe-Khorkaya \\
2. Ussiniskaya
\end{tabular} & $\begin{array}{l}\text { Mataisky } \\
\text { Ussurisky }\end{array}$ & $\begin{array}{l}\text { Ea, Ec, Ee } \\
\text { B, C, D }\end{array}$ \\
\hline \multicolumn{4}{|c|}{ 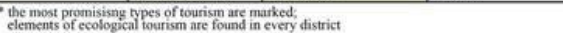 } \\
\hline \multicolumn{4}{|c|}{ 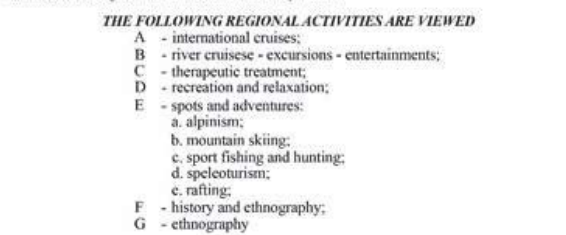 } \\
\hline
\end{tabular}

Figure 2. Legend to map 'Khabarovsky Krai Tourism Zoning' 


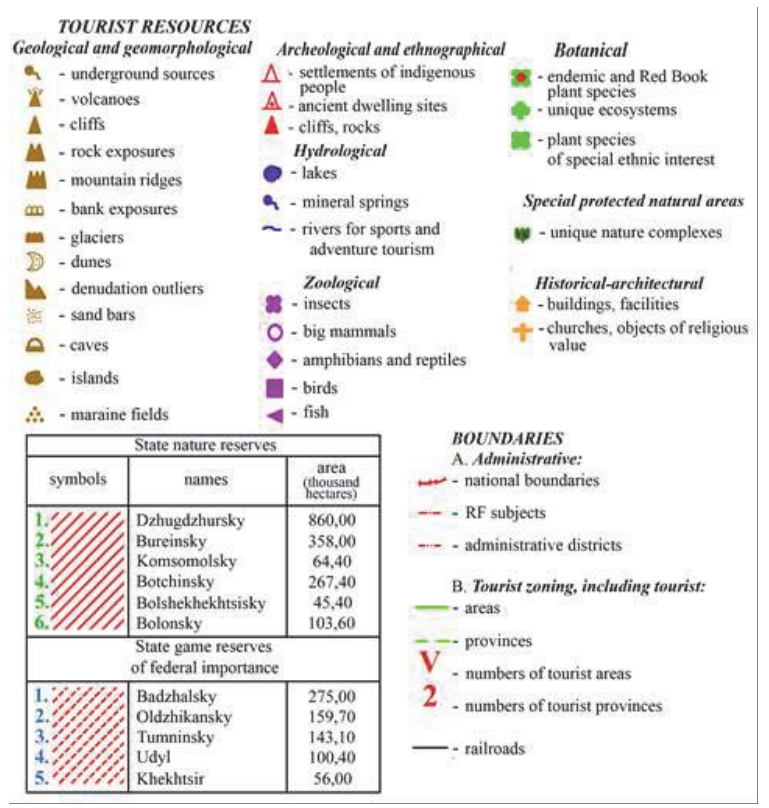

Figure 3. Legend to map 'Khabarovsky Krai Tourism Zoning'

To make the target territory differentiation easier to understand, each contour has its own name. As a rule, these names are similar or correlate with the names of geographical objects (mountain massifs, big rivers, settlements, etc.). Application of such method helps to form a complete image of a certain territory and to make geographical snapping of taxonomic objects more concrete.

Irrespective of their content all zoning systems are characterized with a hierarchy of selected territory units and their taxonomic interdependence. When the map montage was designed such physical and geographical zoning terms were used to name the ranks as «area», «province» and «district». Boundaries of territory units and areas were drawn as described (Mirzekhanova et al., 2005).

Selection of territory units and their taxonomic hierarchy within Khabarovsky Krai (tourist area - tourist province tourist district) were based on compatibility and combination of resources that may predetermine the development of particular types of tourism within large natural complexes.

Tourist area. It is allocated at macro level taking into account natural features of a structure of the territory of Khabarovsk territory, expressiveness of large natural boundaries.

Tourist province. Differentiation of natural systems at middle level is carried out.

Tourist district. Criteria of allocation: concentration of tourist resources, their attractiveness, transport availability, economic feasibility of involvement in tourist activity, focus on service of the population of the region, the country and tourists from abroad etc.

Khabarovsky Krai has a large territory and tourist resources there, their concentration, accessibility, transport infrastructure and information availability are different. That is why tourist districts were selected at the lowest hierarchic level to make possible the effective development and management of tourism activities (Hector 1996; Mountains of the world 1999; Alexandrova 2003; Kotlyarov 1978; Eagles et al., 2002; Timothy 2008; Kropinova \& Mitrofanova 2010). Tourist districts are viewed as sustainable development and investment priorities.

Abundant strongly marked mountain landscapes contrast few plain landscapes in Khabarovsky Krai. Such krai territory specifics determined the selection of a tourist area as the largest hierarchic level. The boundaries of ten tourist areas coincide with the main contours of natural differentiation at the macro-level and the boundaries of tourist provinces coincide with the boundaries of natural systems of the meso-level (Figures 1 and 2).

Tourist activities are not evenly distributed in the tourist district. They are located in certain parts of the district, where most unique and demanded natural, historical and cultural attractions are concentrated and tourist routes meet. The rest of the district territory may be the zone of recreation. That is why the boundaries of the districts are rather vague 
and not concrete.

The multi-colored map legend can be easily reading. Each tourist area and province has its numerical code marked in Roman and Arab figures. Each mapped tourist district provided with information on promising types of tourism in the table (matrix) form. In addition, elements of ecological and educational tourism indicated for each tourist district. Most promising types of tourism (therapeutic treatment, rest and relaxation, sports and adventure, history and ethnography) are marked in the legend with Russian letter codes. Linear signs are used for boundaries of tourist areas and provinces. As tourist districts in Khabarovsky Krai are only being formed, they are marked on the author's original montage with the same color as the taxonomic unit of a higher rank (a tourist area or a tourist province), but of a more intense tone.

II. Tourist resources. This sub-section of the complex thematic map is rather traditional for other tourist maps and contains various inventory and evaluation data. Inventory information describes the variety of tourist resources in Khabarovsky Krai. The register and cadaster of tourism resources (Mirzekhanova et al., 2005) were used as information sources for object mapping. Various information technologies were applied to provide better synthesis of diversified materials. The principle of commonality of the elements of tourist object content and cartographical representation was applied to make the map demonstrative and easy to read.

All tourist resources marked on the Khabarovsk Krai Tourism Zoning Map are divided according to the legend rubrication into the following six groups: geological and geomorphological; hydrological; botanical; zoological; archeological and ethnographical, and special protected areas. A standard set of signs and areals was used. Linear signs show the boundaries of special protected areas (state natural reserves and federal game reserves).

\section{Concluding Remarks}

1. Tourism zoning is an effective method of systematization of information about the territories of various ranks for justifiable of the perspective directions for sustainable development.

2. The executed tourism zoning of Khabarovsk Krai taking into account its environment allowed:

a) to carry out differentiation of the territory of the region;

b) from the point of view of possibilities of development of internal tourism;

c) to show a wide range of tourist resources known today;

d) to allocate the most perspective tourist areas.

3. The resulting materials were used in the development of the regional target program 'Development of internal and external tourism in the Khabarovsk Krai (2013-2020)'.

\section{References}

Alexandrova, A. Yu. (2003). The Market Model of Social-Economic System of Tourism. In Geography of International Tourism (pp. 1533). Moscow: MSU Publ.

Dragiliva, I.I., \& Korneevets, V.S. (2004). A comparative analysis of tourism development in Poland and Kaliningrad oblast. The border zone tourist in chosen post-socialist countries. Coastal region 7. Gdynia: Pelplin.

Eagles, P.E.J., McCool, S.F., \& Haynes, C.D. (2002). Sustainable Tourism in Protected Areas: Guidelines for Planning and Management. Best Practice Protected Area Guidelines Series, 8. IUCN.

Hector, C.-L. (1996). Tourism, ecotourism and protected areas: the state of nature-based tourism around the world and guidelines for its development. Gland, Cambridge: IUCN.

Isachenko, A. G. (2004). Theory and Methods of Geographical Science. Moscow: Academia Publ.

Kobakhidze, E. D. (1978). New Data on Recreational Zoning. In Problems of Regional Organization of Tourism and Recreation (pp. 3133). Stavropol.

Kotlyarov, E. A. (1978). Geography of Recreation and Tourism: Establishing and Developing Territory Recreation Facilities. Moscow: Mysl.

Kropinova, E.G., \& Mitrofanova, A.V. (2010). Modern tourism zoning approaches of Kaliningrad oblast $\quad$ researchers. Izvestiia Tyla State University, 1, 197-209.

Mirzekhanova, Z. G., Debelaya, I. D., Maslichenko, V. A., \& Karjya, N. S. (2005). Guidelines for the Tourist Resource Cadastre (Khabarovsky Krai as an Example). Khabarovsk, Vladivostok: FEB RAS.

Mountains of the world: Tourism and Sustainable Mountain Development (1999). Agenda Institute of Geography, University of Berne, Switzerland. [Online] Available: http://mtnforum.org/sites/default/files/pub/378.rdf (February 25, 2015).

Timothy, D.J. (2008). Relationships between Tourism and International Boundaries. In H. Wachowiak (ed.) Tourism and borders: contemporary issues, policies and international research. New direction in tourism analysis. Burlington: Ashgate. 